\title{
Parenting: Examples from Male/Female Literary Works
}

\author{
Dr. (Mrs) E. D. Simon \\ Centre for General Studies \\ Cross River University of Technology \\ Calabar, Cross River State, Nigeria, Africa \\ E-mail: mssimon64@yahoo.com, Phone: 08037208487 \\ Mrs Obonganwan E. Edim \\ Department of Mass Communication \\ Cross River University of Technology \\ Calabar, Cross River State, Nigeria, Africa \\ E-mail: elmina02@yahoo.com,Phone: 08037208487
}

Doi:10.5901/mjss.2013.v4n6p21

\begin{abstract}
The task of parenting is an enormous one which often put pressure on mothers, fathers, brothers, sisters, uncles, aunts and the rest of society. As the population of the world increases rapidly every day, urgent steps must be taken to stem the tide of crime, violence, drugs abuse, delinquency, school drop-out, teenage pregnancies etc in the society. Most of the delinquent behaviours are caused by negligence on the part of parents to live up to their responsibilities while others are due to peer group pressure. In the absence of parental upbringing and care-givers, children turn to other socialization agencies like the ICT, films, videos, radios, books, social networks like the Facebook, Twitter, Whatsapp etc to learn new and more fascinating ways of getting acceptability. It is therefore important for parents to watch over their children, know the types of friends and companies they keep so that they do not fall prey to social vices. This paper seeks to explore different forms of parenting in select-African novels, as well as show the need for parents to be committed to the parenting of their children/wards. The paper argues that parents as a matter of exigency spend quality time with their children so as to guide them through the process of growth and development. The future of our children and indeed the society lie in proper parenting so that they do not become delinquents and rabble-rousers in the society.
\end{abstract}

\section{Preamble}

Parenting is an important obligation not only for father and mother but the entire society at large. With the high rate of crime, delinquency, poverty and all sorts of oddities in the society, occasioned by Western influences like ICT, films, television, videos, facebook, internet viewing and other socialization agencies, there is dire need for parents to contribute meaningfully to the physical, health, academic, moral, spiritual as well as psychological development of children. Children therefore need proper guidance and counseling from their parents.

Denga and Denga define parenting as "the activity which involves bringing up and looking after a child or children" (1). These critics argue that the process of parenting maybe carried out by biological or blood parents, or a parent in the case of single parents. They further argue that "the process may also involve surrogate parents (step-parents or special care-givers) who are not the real parent but are acting in loco parentis) in view of the biological or blood parents" (1).

In the past, adoption of children was seen as a taboo especially in the African milieu. This trend has changed as many families/couples are keying into this option in order to fulfill their yearning of parenthood. Couples who have no children of their own may adopt a child or children and parent them like their biological children. Most couples who opt for adoption maybe blessed later in life with their own biological children. This follows the belief that if adopted children are well cared for psychologically, materially and otherwise, God in His infinite mercy will certainly reward such parents.

Denga and Denga view parenting as a badge of honour. Parents who have children see themselves as fulfilled especially as African culture frowns at barrenness. African society/culture place premium on marriage because it is the gateway to parenting. This is why married couples without children will do everything humanly and spiritually possible to have children to parent. Ironically, many couples from the high socio-economic status lack children while it is the reverse in homes with low socio-economic status. This myth is difficult to explain. Again, many modern parents are too busy to raise their children. This is probably due to the craze for materialism, poverty, ignorance, urbanization among others. 
These parents often leave their children in the care of househelps/care givers to parent. Most of these househelps/caregivers are children themselves and therefore inexperience to do the odious task given to them. In some parts of Africa and in Nigeria, specifically, househelps have done more harm and damage to the children they are supposed to be taking care of. These form of damage and harm range from sexual to physical abuses as well as spiritual damage to the children's psyche.

In trying to keep up with Western trend, some zealous groups of men/women have set up NGOs who help in procuring househelps and child-minders for desperate families. Most of these child-minders come from dubious backgrounds and the fate of innocent children rest in their hands. Some care-givers are victims of child trafficking, childleasing and child neglect. Again, with the high rate of poverty and wickedness, some minders arrange for children to be sold, kidnapped or used for rituals. It is therefore imperative for parents to create time for their children, show them filial love, teach them morals that will enable them grow into strong citizens and future leaders of the society. Inadequate parenting will produce criminals and delinquent children. Henry Tischer submits that antisocial behaviours "mold individuals, shape their behavour and thus determine social events" (360).

\section{Parenting Types and Examples in Literature}

Africa is a vast continent with diverse cultures and ethnic groups. The continent is endowed with great men and women who practice different forms of parenting. These forms of parenting include strict parenting, surrogate parenting, communal parenting, laissez faire parenting as well as neglectful parenting. Literature mirrors society and is therefore replete with all these examples of parenting. These forms of parenting are all interrelated.

A typical example of strict parenting is demonstrated in Chinua Achebe's Things Fall Apart. In this novel, Okonkwo the protagonist fathers many children from his three wives and brings them up with a "heavy hand" (Things Fall Apart, p.9). This is to say that he is very strict in his method of parenting and show them little or no affection. The only child Okonkwo really shows affection is Ezinma, because she is an only child of her mother, Ekwefi. Rose Acholonu writes that "down in Okonkwo's heart lurks the stifled emotion of love which once gave birth to his amorous relationship with Ekwefi. Thus even in Okonkwo's apparently emotion - starved life, there are glimpses of romance, affection and tenderness..." (93). He goes in search of Ezinma, when she is taken to the "cave mouth" by Chielo, the priestess of Agbada in the middle of the night. While in exile, Okonkwo discourages her from taking a husband from there, especially as she'd grown into a "bunch of crystal beauty" (Things Fall Apart, p.122). She establishes a filial bond with her father as he guides and parents her through life. Florence Orabueze recalls that "a man who has a daughter he loves very much may still wish the girl were a boy" (109). Dorothy Dinnerstein adds that "fathers who want to bring their daughters up as "little women" will actively discourage our efforts to break out of the conventional restrictions of our female role... they will let us know that straight-forward competition will not earn paternal respect" (80-81). Bates et al cite a classical example that "when Elizabeth Cady Stanton (1815-1902) strove for and won a first-place Latin award in school in order to compensate her father for the son he had lost, her father sighed heavily, "you should have been a boy" (231). In the same vein Okonkwo "never stopped regretting that Ezinma was a girl. Of all his children she alone understood his every mood. A bond of sympathy had grown between them as the years passed" (Things Fall Apart, p.122).

On the contrary, Okonkwo did not show any emotions towards his sons especially his first son, Nwoye. This is because the African traditional society, according to Solomon lyasere is "notable for its clear division of sex roles which are informed and controlled by the masculine and feminine principles" (104). Therefore in parenting Nwoye at the tender age of twelve, Okonkwo beats him up because of his laziness. Odejobi Omobola (2012) cites Babatunde's (1992:21) claim that the flogging/spanking is seen as an act of kindness aimed at preventing the child from becoming a difficult person, or at protecting them from true danger. This is born out of the patriarchal ideology which endorses strength, continuity of lineage and achievement which first sons especially and other sons must imbibe. Indeed, Okonkwo did not want his sons to be like his own father, Unoka. Achebe writes:

Okonkwo ruled his household with a heavy hand. His wives especially the youngest lived in perpetual fear of his fiery temper, and so did his little children. Perhaps down in his heart Okonkwo was not a cruel man. But his whole life was dominated by fear, the fear of failure and of himself lest he should be found to resemble his father (Things Fall Apart, p.9 - 10).

This is perhaps why the Browns (2003) cited by Denga and Denga affirm that "boys need fathers to model manhood, to affirm their maleness and validate their self - worth" (46). 
It is remarkable to note that it is Ikemefuna, the lad given to Umuofia as ransome who helps in shaping Nwoye's life. Ikemefuna is Okonkwo's surrogate son. He is handed over to Okonkwo to parent and the latter officially hands the lad to his first wife for proper moral, physical and emotional care. Ikemefuna then grows up in Okonkwo household and becomes a member of the extended family. By handing Ikemefuna to his first wife Okonkwo underscores the importance of first and senior wives in the polygamous setting, because they act as the mother of the entire family/household and oversee the activities of other wives and children. This woman parents and counsels Ikemefuna as one of her own children and showered him with love and kindness. Okonkwo himself "never showed any emotion openly unless it be the emotion of anger. To show affection was a sign of weakness, the only thing worth demonstrating is strength. He therefore treated lkemefuna as he treated everybody else - with a heavy hand. But there was no doubt that he liked the boy... and indeed Ikemefuna called him father" (Things Fall Apart, p.20).

In parenting Ikemefuna, Okonkwo made him carry his goatskin bag and accompany him to meetings as well as social gatherings. He told Nwoye and Ikemefuna stories of valour. As their bond of intimacy grew, Ogbuefi Ezeudu, the oldest man in Umuofia warns Okonkwo not to have a hand in Ikemefuna's death. Through the use of stream of thought technique, Achebe probes Ikemefuna's mind: "he could hardly imagine that Okonkwo was not his real father. He had never been fond of his real father and at the end of the three years he had become very distant indeed" (Things Fall Apart, p. 42) Even in death, the lad still called him father but the confidence Ikemefuna had in Okonkwo, is betrayed as the latter cuts him down because he did not want to be seen as weak. Okonkwo's extremism robs him of humanism, which is an essential attribute of life. Ikemefuna's death tortures Okonkwo for days, setting the stage for his find fall from grace. Obierika his close ally reprimands him thus: "what you have done will not please the earth. It is the kind of action for which the goddess wipes out whole families" (Things Fall Apart, p.46).

The killing of Ikemefuna estranges Nwoye from his father. The role-model image he had built around Okonkwo disappears and in order to spite and assert himself, he betrays his father by joining the Christian sect. Nwoye in a dramatic role reversal tells his father's crony, Obierika "... He is not my father" (Things Fall Apart, p.101). When the full weight of Nwoye's betrayal dawns on Okonkwo, he reasons thus: "how could he have begotten a son like Nwoye, degenerate and effeminate? Perhaps, he was not his son. No, he could not be" (Things Fall Apart, p.108). Okonkwo concludes that "living fire begets cold impotent ash (p.109). Okonkwo resolves that since he had five other sons, he will parent them according to the traditional ways of his community. He however cautions his sons on going against his wishes and risk being disinherited like Nwoye. In this respect, Okonkwo can be likened to another strict-parent, Baba in Zaynab Alkali's, The Stillborn, who disinherits Sule his first son for impregnating a village teenager. Kala, Baba's aged father is a traditionalist who is against his son's method of parenting his children. Alkali describes this mode of parenting as "mad obsession with discipline" (The Stillborn, p.25). This author state clearly through Kaka that- "children shouldn't be caged, ... for if the cage got broken by accident or design they would find the world too big to live in" (The Stillborn, p.25). This is perhaps why Owolabi (1999) cited by Omobola (2012:310) contends that "parenting in African context is autocratic, not democratic especially during the formative years of a child".

Achebe also demonstrates instances of communal parenting in Things Fall Apart. Communal parenting entails that a child/children do not belong to their biological parents only but to the entire community. The community and its members watch over every child and any mother/father can correct or reprimand any erring child in the community irrespective of economic, religious or social status of the parents. In this traditional society, the man is the bread winner, while the women perform domestic duties. The children are to obey their parents and internalize their values and beliefs. Babatunde (1992) cited by Omobola (2012: 310) avers that "in the communal atmosphere of the traditional family, parents of children who behave in approved ways are equally approved as successful. In the same vein, parents whose children misbehave are shamed and advised to put their houses in order. The ancient family according to Atemie and Akikibofori therefore, consist not only of parents and children but uncles, aunts, nephews, nieces, cousins, grand parents etc. These relatives were united and bound together throughout their lives in a system of mutual rights and duties. These critics state thus:

When couples marry, they are already members of the families of origin into which they were born. In this case, three families are involved in the marriage-the husband's family of origin, the wife's family of origin and the newly created family of marriage made by the couple. Each member of the extended family has a stake in the upbringing of the child born by the newly created marriage of the couples (387).

The above claim reiterates the fact that people are communally related to each other. Omobola reiterates this fact when she argues that "parents as the primary agents in the socialization of children make and enforce rules in the home 
and made clear to the children. It then becomes the duty of adults in the society to take that child and create out of him/her a useful social being. The kind of person a child would be is determined by adults' interest and goals especially by parents and other adults in the family and community" (310).

In Things Fall Apart therefore, Okonkwo's wives are saddled with the responsibility of parenting not only their own children but every child in their husband's household and beyond. For instance, Nwoye's mother feeds and watches over Ojiugo's children when the latter goes to plait her hair at her friend's place. However, with changes in socio-cultural values and modernity, this scenario is fast changing as parents/families can misinterpret this kind gesture.

If Okonkwo is seen as a strict father, Unoka, his father epitomizes instances of neglectful parenting. John Santrock points out that "neglectful parenting is a style in which parents are uninterested in their child's life" (342). Unoka was a failure, a loafer who could not provide for his family. Achebe writes that "Unoka, the grown-up was a failure. He was poor and his wife and children had barely enough to eat..." (Things Fall Apart, p.4). Unoka spent all his money drinking and making merry, borrowing and owing. He had no time to guide and counsel his children, hence Okonkwo had to carve a niche for himself in his community.

Unoka's example calls to mind Musa Musa's example in Ama Ata Aidoo's Changes: A Love Story. Musa Musa, Ali Kondey's philandering father, after the death of his teenage wife, passed Ali to his sister Mma Danjuma, who became the boy's surrogate mother. She parented Ali alongside her numerous children. Ali acquired good morals and educational upbringing from Mma Danjuma, whom he came to really love and cherish. He becomes a successful business man, with businesses all over the globe. As a parent himself, he ensured that he and his wife Fusena brought up their children properly. To ensure this, he provided lavishly for them, sent all his children to good schools and refused to allow his educated wife engage in white collar job or further her education. Rather, he opens a big shop for her to manage at her convenience, so as to have more time with the children's upbringing.

Again in Changes: A Love Storey, Opukuya views parenting as a serious matter. She is committed to raising her children properly despite her busy job as a nurse. She finds time to clean and cook for her four children. When she had to travel to visit her mother, she makes adequate arrangements to leave her children with her sister-in-law Connie. Today, some parents are so neglectful that they simply lock their children indoors, without adequate arrangements and take off. Connie assures Opokuya that "all would be fine for the kids to come, of course. And anyway what is this business of coming all the way here just to ask whether the children would stay with me while you are away? Isn't my house their home....? You shouldn't worry about a thing. You can go away whenever it is convenient for you" (Changes, p.65). This is another instance of communal parenting and filial bonding which African society endorse.

The above instance agrees with the theory of structural functionalism which explains the workability of society, the family and its relationship to the large society and how youths/children are central in the society. Atemie and Akikibofori argue thus:
In applying the theory for the understanding of the family, three aspects of the family are looked into. First, what functions the family serves for society; Second, what functional requirements are performed by its members for the family's survivals; and Third, what needs the family requires for its individual members especially in providing for the youths that the families have brought... (389).

Unlike Opokuya, Esi the protagonist of Changes is happy to leave her only child with her mother-in-law. Esi is satisfied with this laissez - faire arrangement since it givens her enough time to spend with her lover, Ali Kondey. One of Esi's major problem with Oko, her ex-husband is that the latter wants many children to parent, whereas Esi seems satisfied with just one child in a traditional setting where children are cherished.

In Helon Habila's Measuring Time, Lamang, the father of the twin, Mamo and LaMamo exemplifies neglectful parenting. Lamang's wife had died as the twin came into the world. Lamang, busy with business and philandering, gave the boys first to his brother's wife Aunt Amina who parented them until they were three years old. One day, he unceremoniously took them and dumped on his sister Aunt Marina, who became their surrogate mother. Lamang is a distant father, who is more interested in pursuing women and a political career than being a father.

As the boys grow to love and respect Aunt Marina because of the physical, emotional and health care she gave them especially Mamo who suffers from sickle-cell, the distance between them and their father grew wider, hence their desire to run away from home. Aunt Marina tells Mamo stories to encourage him and reduce her own loneliness as she'd left her abusive husband and was childless. She taught them good manners, though they were often mischievous, restless and rebellious. The boys had everything except their father's love. Habila writes that "he only spent about a week at home every month, and whenever he came back, he'd look at them with astonishment, as if remembering suddenly 
that he had two sons. He always struggled to remember their names and when he did remember, he invariably mixed them up even though they were not identical..." (Measuring Time, p. 48).

Poor parenting may result in antisocial activities among children/youths. It is therefore not surprising that the twins plot their father's down fall. Mamo writes thus:

\title{
"HATE THY FATHER, MAKE HIM PAY" (Measuring Time, p.20).
}

With this feeling of deprivation and neglect, the boys patronized socialization agencies like the media-radio, television, film, read radical books and magazines which equipped them with social vices. They perfected the act of lying and played expensive prangs on their father and, other members of the Keti community.

At sixteen, the twins decide to run away from home to become soldiers and seek fame. They want to traverse the world like the legendary Mongo Park and enrol in the rebel army. LaMamo succeeds, while his brother is trapped because of his sickle cell disease. Mamo tells Lamang and Aunt Marina: "we wanted to travel... by boat... on the Niger, like Mango Park... but in the opposite direction from Bussa up to Bamako, then by land to Timbuktu..." (Measuring Time p.57). References to Mungo Park and Timbuktu are historical allusions that the boys have built their fantasies on. On his part, Lamang is not concerned about the health or safety of his boys but on what people will say, if the boys had died, how they will blame him for his negligence. Lamang therefore fails "to act or affirm and tighten by cultural inventions his unsatisfactory loose mammalian connection with his children", (80) to borrow Dorothy Dinnerstein's expression.

Atemie and Akikibofori are of the opinion that:

\begin{abstract}
the loss of the exclusive socialization function of the family has had two major impacts on the rest of the social structure. First, it is inevitable that some parents will come into conflict with their biologically mature yet still dependent offspring... This is a particular strain on the inability to be socialized properly. Secondly by socializing children though multiple socialization agencies, we have quicked the process of social change.... It is very difficult for parents to compete with commercial messages of consumption and material success, particularly when the messages are designed by experts. It is even more difficult for parents to complete with the implicit (yet highly and seductive) images of sexuality and violence that are a part of the mass media message (384).
\end{abstract}

Mamo enjoys tutoring his father and refuses to divulge any information about his brother's where about. This is his way of making his father pay for neglecting them.

However, Mamo makes an impact when Pastor Mela helps in show-casing his essay, yet Lamang is uninterested. He merely flipped through the pages and drops the book: "I'll look at it later - I am in a hurry right now" (160). There is no word of encouragement for his son. Uncle lliya, Lamang's brother encourages Mamo's writing career, while the editor steers Mamo from straight history to biography, encouraging him to model his writing on Plutarch's Parallel Lives. Uncle lliya tells Mamo:

\begin{abstract}
no one in this village has done this before. This is great, you have put us on the international map. Now you have to go on and write a book. We'll make a copy and put it on our notice board. l'll also send a copy to our local government chairman and to the Mai's palace. This will show them the caliber of teachers we have here and if they are smart they will see how important education is to our village (Measuring Time, p.160).
\end{abstract}

Mamo's writing elevates not only his family but the entire Keti community. He is given an office in the Mai's palace as well as a guest house where all sorts of immorality reign. He soon learns about the corruption, sexual immorality, deceit and betrayal of Keti leaders.

Meanwhile, LaMamo returns from war as a freedom fighter to lead the protest to the Mai's palace. He asks briefly about Lamang whom he had been estranged from for years. As a freedom fighter, he shows no emotion for his father. He is rather more concerned about the plight of the suffering people of Keti, hence his endorsement of violence. Remi Anifowose points out that:

Individuals and groups throughout history have in one form or another, resorted to violence, or its potential use as a tactic of political action. Violence has been pursued in the defence of order by the privileged, in the name of justice by the oppressed and in fear of displacement by the threatened (1).

LaMamo leads the villagers on the path of violence because he wants justice for his people and because the Mai and Waziri, the traditional fathers of Keti have betrayed their children, the Kelt people, whom they were supposed to lead 
and guide, just as his father, Lamang had betrayed and neglected them. LaMamo's perception of violence tallies with Ngugi wa Thiongo's position which is deeply rooted in Marxist ideological stance. Ngugi submits that "violence in order to change an intolerable, unjust social order is not savagery: it purifies man. Violence to protect and preserve an unjust, oppressive social order is criminal and diminishes man" (28).

Ironically, it is the presence of repressive forces that stalls the protest and violence and leads to the death of many and LaMamo, who had earlier survived all the fierce battles in Chad, Libya etc as a freedom fighter. Charles Tilly opines that "repressive forces do the largest part of the killing and wounding, while the group they are seeking to control do most of the damage to property" (174). This is the plight of the Keti people LaMamo tells his brother before he dies to parent his unborn child. In so doing he foresees a brighter future for his child as the child will grow up being loved and cared for not neglected as was their case with their philandering father. Asabar, the twins' cousin was irresponsible. He engaged himself in negative vices like thurgery and selling of marijuana. He could not parent his son. His father raised his son Markus for him. He is a neglectful parent like his uncle, Lamang.

\section{Conclusion}

Parenting is the traditionally assigned role for not only parents, uncles, aunts etc but the society at large. Parenting entails commitment, patience, love and mutual understanding if children are to be raised properly. As the world becomes globalised, coupled with modern modes of living, ICT, video, facebook and peer groups influence, there is need for parents to pay serious attention to their children. When they have to leave them with relatives, househelp etc, they must find time to monitor them in order to ensure that they are properly parented. Parents need to provide physical, health, economic and emotional enablements for the growth and development of children. It is also necessary for parents to show children love and respect. Being too strict can also affect the children physically and psychologically. It is against this backdrop that parenting should be carefully undertaken in order to stem the tide of undue embarrassment, violence, drug abuse and other unwholesome behaviours in the society. These will in turn promote national and global peace in the society.

\section{References}

Acholonu, Rose. Family Love in Nigerian Fiction: Feminist Perspective, Owerri: Achisons Publication, 1995.

Achebe, Chinua. Things Fall Apart. London: Heinemann, 1958.

Aidoo, Ama Ata. Changes: A Love Story. London: Heinemann, 1991.

Alkali, Zaynab. The Stillborn, Lagos: Longman, 1984.

Anifowose, Remi. Violence and Politics in Nigeria, Enugu: Nok Publishers, 1982.

Atemie, J.D. and Akikibofori, J. S. "Moral Decadence and Youth Restiveness in the Niger Delta Region of Nigeria: A Theoretic Analysis of an Antisocial Behaviour". The Future of the Niger Delta: The Search for Relevant Narrative. Ed. A. A. Derefake and A.M. Okonobia. Port Harcourt: Onyoma Research Publications, 2008:371 - 398.

Babatunde, E. D. Culture, Religion and the Self: A Critical Study of Bini and Yoruba Value Systems in Change. Lewiston: N.Y.: Edwin Metlen Press, 1992.

Bares, Ulku et al. Women's Realities, Women's Choices: An Introduction to Women's Studies New York: Oxford University Press, 1983.

Denga, D. I. and Denga, H. M. Child Parenting in Developing Nations: Challenges and Prospects. Calabar: Rapid Educational Publishes, 2007.

Dinnersterin, Dorothy. The Mermaid and the Minotaur: Sexual Arrangement and Human Malaise. New York: Harper and Row, 1976.

Habila, Helon. Measuring Time. Virginia: W.W. Norton, 2006.

lyasere, Solomon O. "Narrative Technique in Things Fall Apart. Critical Perspectives on Chinua Achebe. Ed. C.L. Innes and Berth Linfors. London: Heinemann, 1979.

Merit, Stephanie. The Observer Sunday 4 February, 2007.

Opara, Chioma. "Woman in a Chequered Nigerian History: A Re-Reading of Chinua Achebe's Novels" Beyond the marginal Land: Gender Perspectives in African Writing. Ed. Chioma Opara. Port Harcourt: Belpot, 1999: 151 - 170.

Omobola, O. C. "Community Parenting and the Concept of Child Abuse in Yoruba Culture". Mediterranean Journal of Social Sciences. Vol. 3, No.2. May 2012:309-316.

Orabueze, Florence. “The Feminist Crusade Against Violation of Women's Fundamental Human Rights: Mariame Ba's So Long a Letter and Buchi Emecheta's Second Class Citizen. Woman in the Academy: Festschrift for Professor Helen Chukwma Ed. Seiyifa Koroye and Noel C. Anyadike. Port Harcourt: Pearl Publishers, 2004: 103-119.

Owolabi, R. O. Effective Parenting: Strategies that Works and Mistakes. U.S.A.: Bob and Bob Publication, 1999.

Santrock, John W. Psychology. Boston: McGraw Hill, 2000.

Stanton, Elizabeth C. Eighty Years and More. Schocken, New York. 1971. 
Tilly, Charles. From Mobilization to Revolution. Reading, Massachusetts: Addison-Wesley Publication, 1978.

Tischler, Henry. Introduction to Sociology. Philadelphia: The Harcourt Press, 1999.

Wa Thiongo, Ngugi. Homecoming: Essays on African and Caribbean Literature, Culture and Politics. London: Heinemann, 1982. 
